\title{
ATTACHED WINTER FLORAL ASSEMBLAGES ON SAND FROM GRAND TRAVERSE BAY, LAKE MICHIGAN *
}

John $C$. Kingston and Rex L. Lowe

Department of Biological Sciences, Bowling Green State University, Bowling Green, Ohio 43403

Eugene F. Stoermer

Great Lakes Research Division, University of Michigan, Ann Arbor,

Michigan 48109

Natural benthic substrates were collected beneath the ice of Grand Traverse Bay by divers on March 10, 1978 as part of a seasonal investigation of northern Lake Michigan benthic algae assemblages. Some of the samples from each selected depth between the surface and $32 \mathrm{~m}$ were examined using SEM. Natural substrates (silt, sand, pebbles, algae, shells) were field-fixed in glutaraldehyde, dehydrated, and critical point dried. Samples were sputter coated and examined with a Hitachi HHS-2R SEM operating at $20 \mathrm{kV}$.

Sand samples from depths of 2,5, and $10 \mathrm{~m}$ supported large populations of live epilithic and epipelic diatoms, as well as green algae, bluegreen algae, and bacteria, as determined by ight microscopy of wet mounts and SEM (Figs. I \& 2). Particularly dominant diatoms in these assemblages are species from the genera Achnanthes, Amphora, Cocconeis, Diatoma, Fragilaria, Navicula, and Opephora.

Several attachment mechanisms to sand grains can be noted. Opephora ansata Hohn \& Hellerman is an example of attachment by hard mucilaginous stalks and interconnection of sibling cells by mucilage pads present at terminal pore fields (Fig. 1). Achnanthes clevei Grunow, Achnanthes clevei var. rostrata Hustedt, and Achnanthes exigua Grunow attach by the soft mucilaginous coating of the raphe valve face (Fig. 2). Nitzschia sp. and Opephora sp. show less determinate attachment by soft mucous layers along girdle bands or valve surfaces (Fig. 2). Anacystis i ncerta Drouet \& Daily and coccoid bacteria attach via fibrillar appendages (Figs. 1 \& 2 ) as Feported by Paerl (l). Bacilliform bacteria are scattered over the sand grains or form colo$n$ ies, and they show irregular mucilaginous connections or no visible attachment mechanism (Figs. I \& 2).

Chironomid larvae are common in some samples, and it is probable that small sand grains are scraped or ingested whole as a means of using these attached organisms for food.

The extensive growth observed on northern Lake Michigan sand confirms others' conclusions that sand is exploited as a preferred habitat by many members of the microflora (Ref. 2).

\section{REFERENCES}

(1) H. W. Paerl, Microbial attachment to particles in marine and freshwater ecosystems, Microbial Ecology 2, 73 (1975).

(2) P. S. Meadows \& J. G. Anderson, Micro-organisms attached to marine and freshwater sand grains, Nature 212, 1059 (1966). 


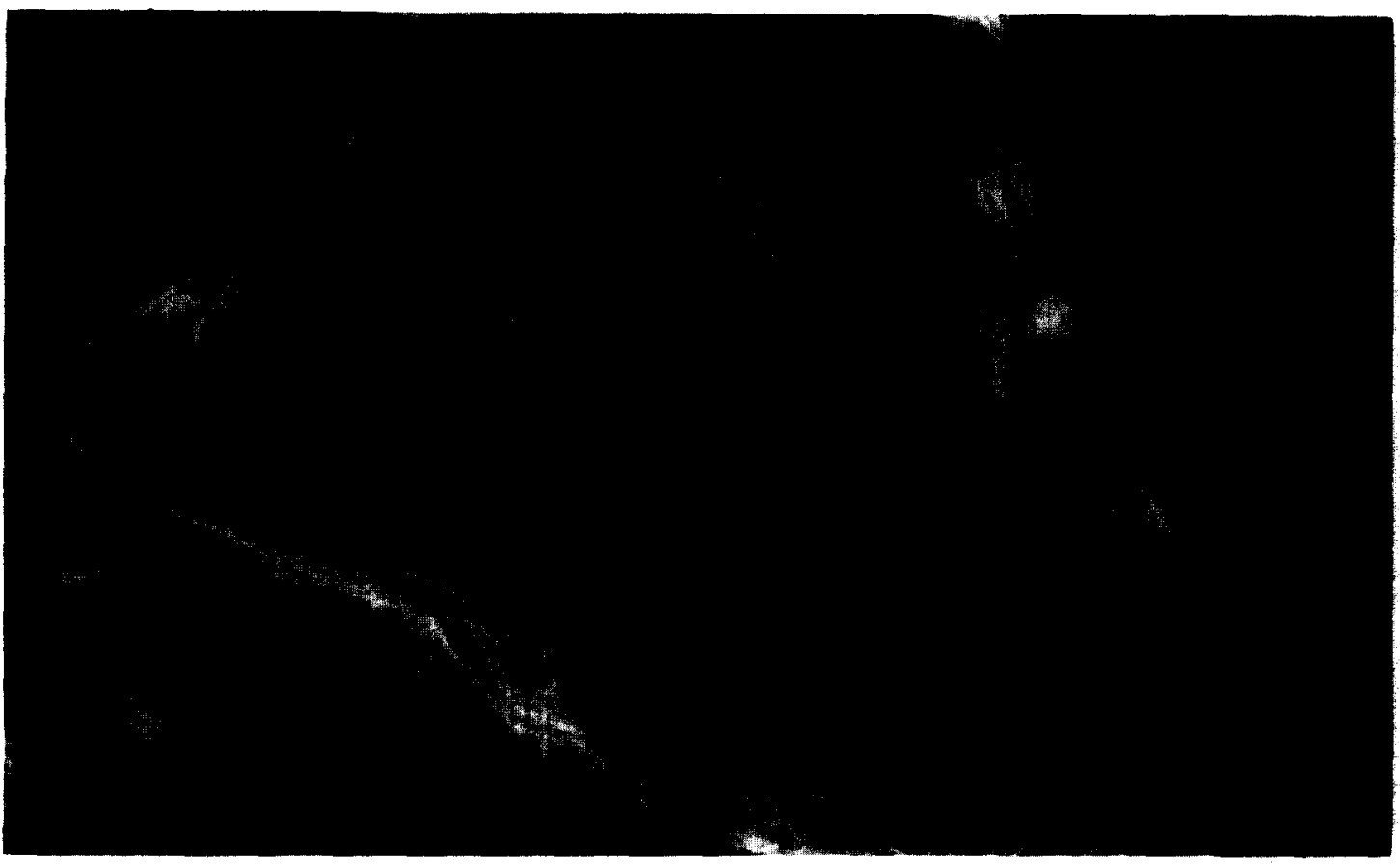

Fig. I SEM of sand from $2 \mathrm{~m}$ with attached opephora ansata (0), Anacystis incerta (A), and bacilliform bacteria (B)

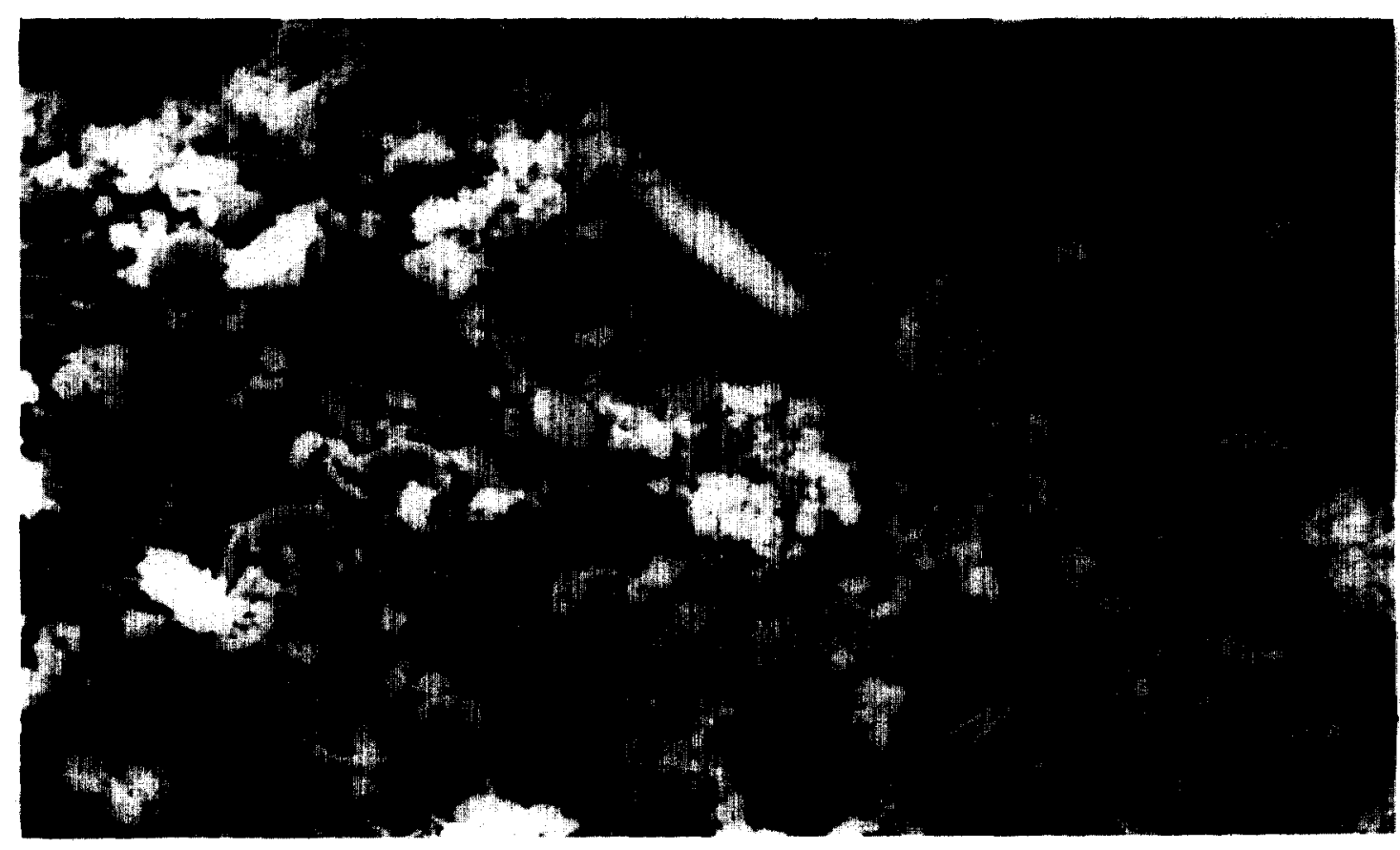

Fig. 2 SEM of sand from $5 \mathrm{~m}$ with attached Achnanthes clevei (C), Achnanthes clevei var. rostrata (R), Achnanthes exigua (E), Opephora $\overline{S p \cdot(S)}$, and Nitzschia $\overline{S P \cdot(N)}$ 